\title{
Type VI Choledochal Cysts-Case Report and Review of Literature
}

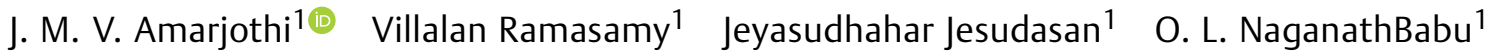 \\ 1 Department of Surgical Gastroenterology, Madras Medical College, Rajiv \\ Gandhi Government General Hospital, Chennai, Tamilnadu, India \\ Surg J 2019;5:e82-e86. \\ Address for correspondence J. M. V. Amarjothi, MS, $\mathrm{McH}$, \\ Department of Surgical Gastroenterology, 500, Tower Block II, Rajiv \\ Gandhi Government General Hospital, Chennai 600003, Tamilnadu, \\ India (e-mail: drmosesvikramamarjothi@hotmail.com).
}

\begin{abstract}
Keywords

- choledochal cyst type VI

- cystic duct cyst

- cholecystectomy

Choledochal cysts $(C D C)$, are rare congenital dilations involving the extra hepatic biliary apparatus with or without dilation of the intrahepatic bile ducts. They are conventionally classified into five types. A new type, type VI, causing dilation of the cystic duct between the neck of the gall bladder and the common hepatic duct (CHD) has been described in medical literature which is the rarest of all these subtypes. They are commonly observed in middle aged females and are mostly symptomatic. Most of these cysts need magnetic resonance cholangiopancreatography (MRCP) for accurate diagnosis. Treatment options for these lesions are not well defined but range from simple cholecystectomy to complete excision of the entire bile duct and biliary reconstruction, as there is a concern of malignant transformation in these cysts. Hence, these rare cysts, though rare, must be borne in mind when dealing with suspicious cystic lesions in the biliary tract. Here, we present an interesting case of such a rare cyst and its management in a middle aged woman.
\end{abstract}

\section{Case Report}

A 40-year-old female presented with complaints of pain in the right side of upper abdomen which was aggravated by fatty meals for 6 months of duration. Clinical examination of abdomen and laboratory tests were normal. Ultrasound of the abdomen revealed a hypoechoic lesion of approximately $3 \mathrm{~cm}$ in size in close proximity to a thickened gall bladder (GB) with few stones in fundus. There was no intrahepatic biliary radicle dilatation (IHBRD). Magnetic resonance cholangiopancreatography (MRCP) revealed a $3 \mathrm{~cm} \times 4 \mathrm{~cm}$ cyst interposed between the GB and the common hepatic duct (CHD), with no IHBRD, CHD, or common bile duct (CBD) dilation (- Fig. 1). A provisional diagnosis of type II/type VI choledochal cyst was made. Patient also had an incidental congenital anomaly involving the uterus (bicornuate uterus) seen on magnetic resonance imaging (MRI; - Fig. 2).

(1)J. M. V. Amarjothi's ORCID is https://orcid.org/0000-0001-96035301.

received

December 2, 2018

accepted after revision

June 12, 2019
DOI https://doi.org/

10.1055/s-0039-1693652. ISSN 2378-5128.
Due to concerns of adhesions and difficult dissection between the cystic duct cyst and CHD, which may result in incomplete cyst excision, open mini-cholecystectomy with cyst excision was planned instead of laparoscopic cyst excision and cholecystectomy.

Intraoperatively, the GB and cystic duct cyst were dissected free from the surrounding structures and the plane between the cystic duct cyst and CHD was clearly defined. As the communication between the cyst and CHD was small, cholecystectomy and complete cyst excision was done.

The postoperative course was uneventful and patient was discharged on postoperative day (POD) 3 after surgery. The specimen revealed a distal contracted GB with minute stones in fundus with cyst proximally ( - Figs. 3 and $\mathbf{4}$ ). Microscopy of the GB showed features suggestive of chronic cholecystitis.

\section{Discussion}

Choledochal cysts (CDC) commonly cause dilations in the extrahepatic bile ducts. They are classified by Todani et al ${ }^{1}$

Copyright $\odot 2019$ by Thieme Medical Publishers, Inc., 333 Seventh Avenue, New York, NY 10001, USA. Tel: +1(212) 584-4662.

\section{License terms}

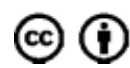




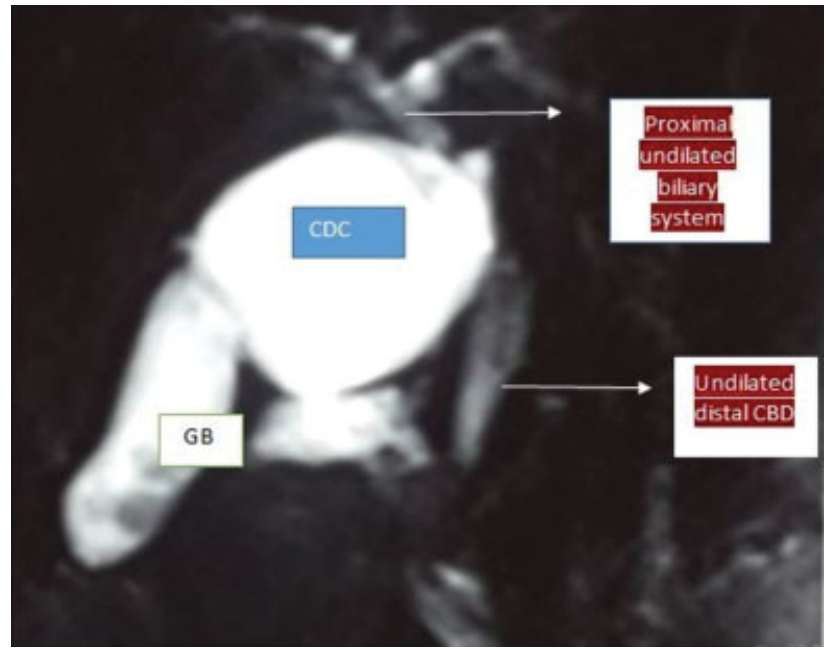

Fig. 1 MRCP showing the contracted distal gall bladder (GB) with proximal cystic duct cyst or type VI choledochal cyst extending upto the undilated common bile. CDC, choledochal cyst; MRCP, magnetic resonance cholangiopancreatography.

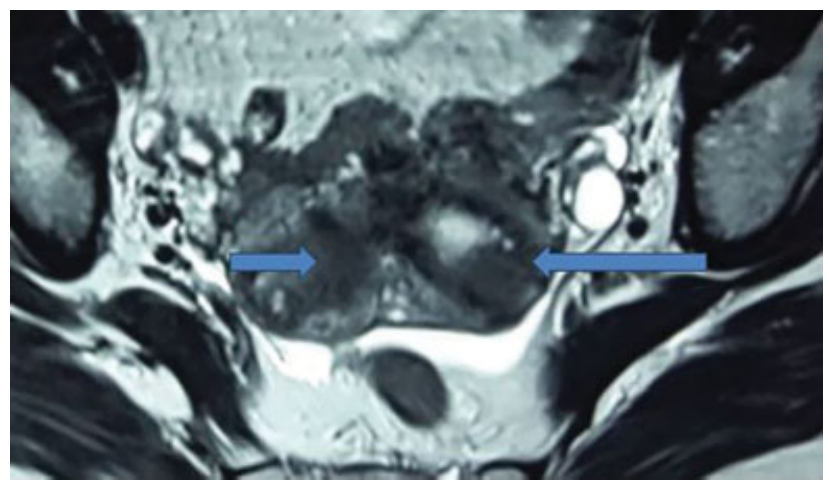

Fig. 2 MRCP showing bicornuate uterus in same patient. (arrows) $\mathrm{MRCP}$, Magnetic resonance cholangiopancreaticography.

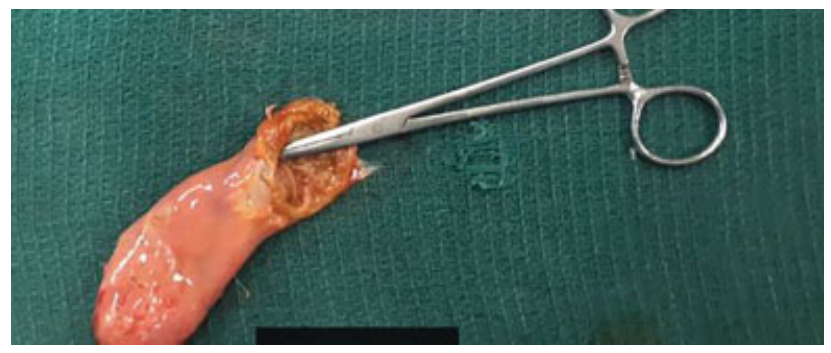

Fig. 3 Post cholecystectomy specimen with opened proximal cystic duct cyst (forceps).

into five subtypes where type I CDC is the most common, (60\%) causing fusiform dilation of the common biliary duct apparatus. Type II involves saccular diverticulum of the CBD, type III involves perivaterian part of CBD, type IV involves multiple focal dilations of the bile ducts which are further subdivided into extrahepatic with intrahepatic involvement (4a) and extra hepatic involvement only ( $4 \mathrm{~b})$. Type $\mathrm{V}$ involves the intrahepatic bile ducts only (Caroli's disease).

Serena Serradel et $\mathrm{al}^{2}$ modified the widely accepted and used classification of Alonso-Lej which was previously mod-

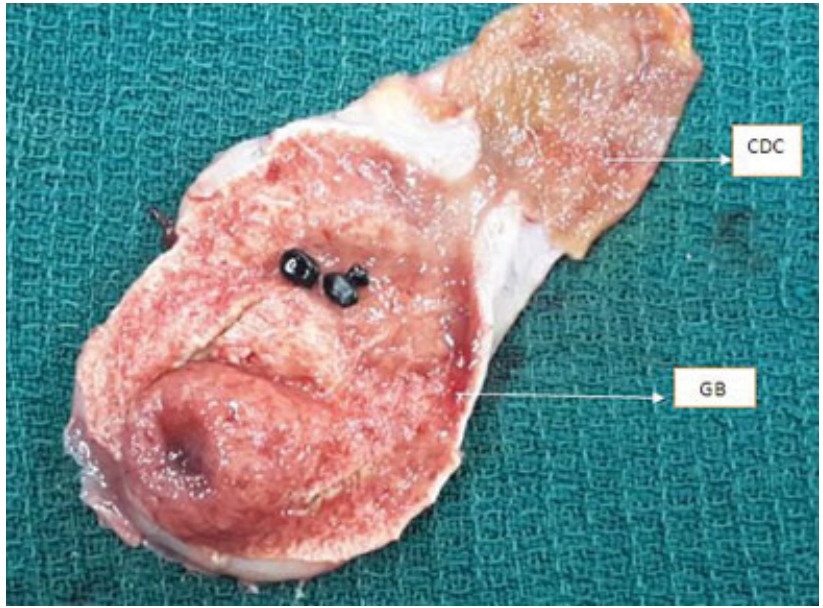

Fig. 4 Post cholecystectomy specimen-longitudinal section showing proximal dilated cystic duct cyst and distal thickened gall bladder (GB) with small stones. CDC, choledochal cyst.

ified by Todani et al $^{1}$ to include cystic duct cysts as a separate entity. Though the first such case was described by Bode and Aust in $1983,{ }^{3}$ these lesions are very rare and only a few cases have been described in literature ( $\boldsymbol{-}$ Table $\mathbf{1}$ ).

Most of these cystic duct lesions are symptomatic with most common symptom being epigastric and/or right upper quadrant pain aggravated by a fatty meal (as in this case). Although the exact etiology of these cysts is unknown, type VI CDC is thought to occur due to ectasia at the cystic duct caused by an abnormal pancreaticobiliary duct junction (APBDJ)., ${ }^{3,13,16}$ An abnormal APBDJ is, however, not seen in all cases and a focal aganglionosis of the cystic duct, such as seen in Hirschsprung's disease, is thought to play a role. ${ }^{25}$

Abdominal ultrasonography is commonly the initial investigation and an MRCP is ideal to delineate the entire biliary system including the course of the cystic duct, presence or absence of ABBDJ, GB thickening, presence of gall stones, IHBRD, and CBD involvement. Endoscopic retrograde cholangiopancreatography (ERCP) is invasive, though providing the same information and detail regarding the biliary system as MRCP. ERCP and Tc-99m Hydroxy Imino Diacetic Acid (HIDA) scan can be used for diagnosis but are not commonly used.

Typical radiologic abnormalities that are specific to type VI CDC includes dilatation and squaring of the cystic duct, acute angulation of the CHD, and cystic duct junction with a distinct plane present between the dilated cystic duct and CHD, a normal or wide (Mirrizi's syndrome) opening of the cystic duct to the CBD, a normal CBD, and associated APBDJ. ${ }^{26}$ Most common differential diagnosis is a type II or type I CDC due to similarities in appearance of cyst in close proximity to CBD. Type VI choledochal cysts can further be described based on morphology as fusiform (more common) and saccular.

As the epithelium of these cysts are prone to develop biliary intraepithelial neoplasia (BIN), onus must be placed on complete surgical excision and multiple cut sections of the histopathology specimen must be analyzed. ${ }^{6}$ This is the 
Table 1 List of cases of type 6 choledochal cysts reported in literature

\begin{tabular}{|c|c|c|c|c|c|c|}
\hline Author & $\begin{array}{l}\text { No of } \\
\text { cases }\end{array}$ & Year & Finding & $\begin{array}{l}\text { Associated biliary } \\
\text { anomalies }\end{array}$ & $\begin{array}{l}\text { Diagnosis: } \\
\text { intraoperative/ } \\
\text { preoperative } \\
(\mathrm{I} / \mathrm{P})\end{array}$ & Management \\
\hline Bode and Aust $^{3}$ & 1 & 1983 & $\begin{array}{l}\text { Dilated cystic duct cyst with } \\
\text { narrow neck }\end{array}$ & Cholangitis & I & $\begin{array}{l}\text { Cholecystectomy, cyst exci- } \\
\text { sion, } \\
\text { choledochoduodenostomy }\end{array}$ \\
\hline${\text { Champetier et } \text { al }^{4}}^{4}$ & 2 & 1987 & Not known & $\begin{array}{l}\text { Case } 1: \text { CBD cyst, case } 2: \\
\text { cholelithiasis }\end{array}$ & $P$ & $\begin{array}{l}\text { Case } 1 \text { : excision of cyst with } \\
\text { bile duct cyst and cholecys- } \\
\text { tectomy; case } 2 \text { : excision of } \\
\text { cyst with cholecystectomy }\end{array}$ \\
\hline $\begin{array}{l}\text { Serena Serradel } \\
\text { et } \mathrm{al}^{2}\end{array}$ & 1 & 1991 & $\begin{array}{l}\text { Cystic dilatation of cystic } \\
\text { duct }\end{array}$ & Cystolithiasis & I & $\begin{array}{l}\text { Cholecystectomy, cystic duct } \\
\text { excision }\end{array}$ \\
\hline Loke et $\mathrm{al}^{5}$ & 1 & 1999 & $\begin{array}{l}\text { Dilated cystic duct with wide } \\
\text { opening into the CBD }\end{array}$ & Cystolithiasis & 1 & $\begin{array}{l}\text { Cholecystectomy, cyst excision } \\
\text { with RYHJ }\end{array}$ \\
\hline 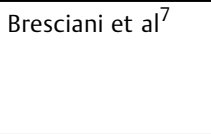 & 1 & 1998 & Cyst of cystic duct & $\begin{array}{l}\text { Anomalous duct joining the } \\
\text { cyst to right hepatic duct }\end{array}$ & 1 & $\begin{array}{l}\text { Video laparoscopic en bloc re- } \\
\text { section of cyst and GB with } \\
\text { ligature with a clip of the cystic } \\
\text { duct and anomalous duct }\end{array}$ \\
\hline Baj et $\mathrm{al}^{8}$ & 1 & 2002 & $\begin{array}{l}\text { Fusiform dilatation, wide } \\
\text { opening }\end{array}$ & $\mathrm{NA}$ & $P$ & Patient refused surgery \\
\hline Weiler et $\mathrm{al}^{9}$ & 1 & 2003 & Not known & APBDJ & $\mathrm{P}$ & $\begin{array}{l}\text { Excision of cyst, CBD with } \\
\text { cholecystectomy and RYHJ }\end{array}$ \\
\hline Manickam et al ${ }^{10}$ & 1 & 2004 & Not known & APBDJ & NA & $\begin{array}{l}\text { Excision of cyst with } \\
\text { cholecystectomy }\end{array}$ \\
\hline Yoon $^{11}$ & 3 & 2011 & $\begin{array}{l}\text { Case 1: fusiform dilatation of } \\
\text { cystic duct; case 2: fusiform } \\
\text { dilatation joining by a wide } \\
\text { opening; case } 3 \text { : fusiform di- } \\
\text { latation with wide opening in } \\
\text { the CBD }\end{array}$ & $\begin{array}{l}\text { Case } 1 \text { : advanced carcino- } \\
\text { ma GB with lymphadenop- } \\
\text { athy; case } 2 \text { : fusiform } \\
\text { dilatation of CBD; case } 3 \text { : } \\
\text { CBD dilatation, GB polyps }\end{array}$ & $\mathrm{P}$ & $\begin{array}{l}\text { Case } 1 \text { : not known; case } 2 \text { : } \\
\text { refused surgery; case } 3 \text { : cyst } \\
\text { excision, } \mathrm{RYHJ}\end{array}$ \\
\hline Chan et al ${ }^{12}$ & 1 & 2009 & $\begin{array}{l}\text { Fusiform dilatation with nar- } \\
\text { row opening in CBD }\end{array}$ & $\begin{array}{l}\text { Cholelithiasis, chronic } \\
\text { Intraoperative }\end{array}$ & 1 & $\begin{array}{l}\text { Laparoscopic excision of the } \\
\text { cyst with cholecystectomy }\end{array}$ \\
\hline Conway et $\mathrm{al}^{13}$ & 1 & 2009 & $\begin{array}{l}\text { Fusiform dilatation with nar- } \\
\text { row opening in CBD }\end{array}$ & Intraoperative & I & $\begin{array}{l}\text { Excision of cystic duct cyst with } \\
\text { cholecystectomy }\end{array}$ \\
\hline Ghatak $^{14}$ & 1 & 2010 & Saccular dilatation & $\begin{array}{l}\text { Fusiform dilatation of CBD } \\
\text { Not known }\end{array}$ & NA & Excision of cyst, CBD, RYHJ' \\
\hline Khanna et al ${ }^{15}$ & 1 & 2010 & $\begin{array}{l}\text { Cystic dilatation with wide } \\
\text { opening into the common } \\
\text { bile duct }\end{array}$ & $\begin{array}{l}\text {-Dilation of CHD, CBD } \\
\text {-Carcinoma gall bladder }\end{array}$ & $P$ & $\begin{array}{l}\text { Excision of cyst, gall bladder, } \\
\text { and common hepatic duct with } \\
\text { hepaticojeunostomy }\end{array}$ \\
\hline De et $\mathrm{al}^{16}$ & 1 & 2011 & $\begin{array}{l}\text { Cystic duct cyst with wide } \\
\text { opening into CBD and nor- } \\
\text { mal distal CBD }\end{array}$ & $\begin{array}{l}\text { Cholecystitis } \\
\text { Intraoperative }\end{array}$ & I & $\begin{array}{l}\text { Excision of cyst, gall bladder, } \\
\text { and distal CBD, } \\
\text { hepaticoenterostomy }\end{array}$ \\
\hline Maheshwari $^{17}$ & 10 & 2012 & $\begin{array}{l}\text { Fusiform dilatation in six, } \\
\text { saccular dilatation in four }\end{array}$ & $\begin{array}{l}1 \text { case-fusiform CBD dila- } \\
\text { tion } \\
1 \text { case-cystic duct calculi } \\
\text { and malignancy }\end{array}$ & $P$ & $\begin{array}{l}\text { Surgical management of cyst: } \\
\text { five cases, details of surgery } \\
\text { not known Surgery for other } \\
\text { indications, no of intervention } \\
\text { for cystic duct cyst: } 1 \text { case; } \\
\text { expectant management: } 3 \\
\text { cases; refused follow-up: } 1 \text { case }\end{array}$ \\
\hline Shah et al ${ }^{18}$ & 1 & 2013 & $\begin{array}{l}\text { Cystic dilatation with wide } \\
\text { opening }\end{array}$ & Cholecystitis & $\mathrm{P}$ & $\begin{array}{l}\text { Excision of cystic duct and part } \\
\text { of CBD with RYHJ }\end{array}$ \\
\hline Mishra et al $^{19}$ & 2 & 2013 & $\begin{array}{l}\text { Case } 1 \text { : fusiform dilatation } \\
\text { with wide opening; case } 2 \text { : } \\
\text { fusiform dilatation of CBD } \\
\text { with a wide opening }\end{array}$ & $\begin{array}{l}\text { Case 1: CBD, diverticulum, } \\
\text { Preoperative choledocho- } \\
\text { cele, cholelithiasis; case 2: } \\
\text { dilated CBD, right and left } \\
\text { hepatic ducts, } \\
\text { cholelithiasis }\end{array}$ & $P$ & $\begin{array}{l}\text { Case 1: excision of CDC with } \\
\text { RYHJ', deroofing of the chole- } \\
\text { dochocele; case 2: CDC exci- } \\
\text { sion with RYHJ }\end{array}$ \\
\hline Kesici et $\mathrm{al}^{20}$ & 1 & 2013 & $\begin{array}{l}\text { Fusiform dilatation of cystic } \\
\text { duct }\end{array}$ & Cholelithiasis & $P$ & $\begin{array}{l}\text { Elective excision of GB and } \\
\text { cystic duct cyst }\end{array}$ \\
\hline Sethi et $\mathrm{al}^{21}$ & 3 & 2015 & $\begin{array}{l}\text { Case 1: cystic dilatation of } \\
\text { cystic duct with wide open- } \\
\text { ing; case } 2 \text { : fusiform dilata- } \\
\text { tion of cystic duct with wide } \\
\text { opening; case } 3 \text { : cystic dila- } \\
\text { tation of cystic duct with } \\
\text { narrow opening }\end{array}$ & $\begin{array}{l}\text { Case 1: carcinoma gall } \\
\text { bladder; case 2: fusiform } \\
\text { dilatation of hepatic duct; } \\
\text { case } 3 \text { : fusiform dilatation } \\
\text { of both hepatic dust and } \\
\text { common hepatic duct }\end{array}$ & $P$ & $\begin{array}{l}\text { Case } 1 \text { : cholecystectomy with } \\
\text { cystic duct cyst excision, re- } \\
\text { moval of CBD with RYHJ; case } \\
\text { 2: cholecystectomy with cystic } \\
\text { duct excision, and CBD exci- } \\
\text { sion with RYH]; case 3: open } \\
\text { cholecystectomy with }\end{array}$ \\
\hline
\end{tabular}


Table 1 (Continued)

\begin{tabular}{|c|c|c|c|c|c|c|}
\hline Author & $\begin{array}{l}\text { No of } \\
\text { cases }\end{array}$ & Year & Finding & $\begin{array}{l}\text { Associated biliary } \\
\text { anomalies }\end{array}$ & $\begin{array}{l}\text { Diagnosis: } \\
\text { intraoperative/ } \\
\text { preoperative } \\
(\mathrm{I} / \mathrm{P})\end{array}$ & Management \\
\hline & & & & & & $\begin{array}{l}\text { complete excision of extra he- } \\
\text { patic biliary ducts with RYHJ } \\
\text { with right and left hepatic } \\
\text { ducts separately }\end{array}$ \\
\hline Çamlıdağ et $\mathrm{al}^{22}$ & 1 & 2015 & $\begin{array}{l}\text { Fusiform dilatation of the } \\
\text { cystic duct with the CBD; } \\
\text { cholangiocarcinoma in distal } \\
\text { part of both cystic duct and } \\
\text { CBD }\end{array}$ & & $\mathrm{P}$ & Whipple's operation \\
\hline Nambiar et $\mathrm{al}^{23}$ & 1 & 2016 & $\begin{array}{l}\text { Fusiform dilatation of the } \\
\text { cystic duct with GB with } \\
\text { distal CBD including } \\
\text { intrapancreatic portion }\end{array}$ & & $\mathrm{P}$ & $\begin{array}{l}\text { Lap converted to open cyst } \\
\text { excision with cholecystectomy } \\
\text { with hepaticojejunostomy }\end{array}$ \\
\hline Ray et $\mathrm{al}^{24}$ & 1 & 2017 & $\begin{array}{l}\text { Fusiform dilation of cystic } \\
\text { duct with no IHBR }\end{array}$ & & $P$ & Laparoscopic cholecystectomy \\
\hline UpadhyayaVD ${ }^{28}$ & 3 & 2018 & dilated cystic duct (3) & dilated $\mathrm{CBD}(3)$ & $\mathrm{I}(3)$ & Cyst excision with RYHJ(3) \\
\hline This case & & 2019 & $\begin{array}{l}\text { Fusiform dilation of cystic } \\
\text { duct with no IHBR }\end{array}$ & & $P$ & Open cholecystectomy \\
\hline
\end{tabular}

Abbreviations: APBDJ, abnormal pancreaticobiliary duct junction; CBD, common bile duct; CDC, choledochal cysts; GB, gall bladder; IHBR, intrahepatic biliary radicle; N/A, not available; RYHJ, Roux-en-Y Hepaticojejunostomy.

rationale for complete surgical excision of the cyst along with cholecystectomy. 27

Hence, the treatment for symptomatic cystic duct cysts is cholecystectomy with complete excision of the cystic duct cyst. ${ }^{1,5}$ For cysts with narrow opening of the cystic duct cyst into CHD, cholecystectomy with complete cystic duct excision alone would suffice and it can be done through laparoscopy by clipping the cyst opening into the CHD. ${ }^{7,16}$ However, if the communication between the cystic duct cyst and CHD is wide, with adhesions precluding safe clipping, an open cyst excision along with Roux-en-Y hepaticojejunostomy as reconstruction may be performed. ${ }^{7,16}$

Bresciani et al, ${ }^{7}$ Chan et al, ${ }^{12}$ and Ray et $\mathrm{al}^{24}$ have reported on the laparoscopic management of the cystic duct cysts where the most common surgery is a laparoscopic cholecystectomy with cystic duct cyst excision. Laparoscopic cholecystectomy with cyst excision can be done with low threshold for conversion to open cholecystectomy in case of anatomical difficulty and associated biliary anomalies which are seen in most reported cases in literature. ( $\mathbf{- T a b l e ~} \mathbf{1}$ )

\section{Conclusion}

The increasing use of MRCP to diagnose hepatobiliary problems will result in an increasing number of such cystic duct dilations in the near future. In today's laparoscopic era, many surgeons may also be faced with such cysts intraoperatively when they are operating on cases of acute cholecystitis or symptomatic biliary cholelithiasis. Hence, knowledge of type VI CDC, its diagnosis by MRCP, and treatment options are the need of the hour for effective treatment and management of this rare entity.
Note

No ethical approval was required for the case report.

Financial Disclosure

The authors have no financial disclosure.

Conflict of Interest

None.

\section{References}

1 Todani T, Watanabe Y, Narusue M, Tabuchi K, Okajima K. Congenital bile duct cysts: Classification, operative procedures, and review of thirty-seven cases including cancer arising from choledochal cyst. Am J Surg 1977;134(02):263269

2 Serena Serradel AF, Santamaría Linares E, Herrera Goepfert R. Cystic dilatation of the cystic duct: a new type of biliary cyst. Surgery 1991;109(3, Pt. 1):320-322

3 Bode WE, Aust JB. Isolated cystic dilatation of the cystic duct. Am J Surg 1983;145(06):828-829

4 Champetier P, Partensky C, Ponchon T. Cystic malformations of the cystic duct. Surg Radiol Anat 1987;9(04):287-291

5 Loke TK, Lam SH, Chan CS. Choledochal cyst: an unusual type of cystic dilatation of the cystic duct. AJR Am J Roentgenol 1999;173 (03):619-620

6 Singham J, Yoshida EM, Scudamore CH. Choledochal cysts. Part 3 of 3: management. Can J Surg 2010;53(01):51-56

7 Bresciani C, Gama-Rodrigues J, Santos VR. Video-laparoscopic treatment of a sizeable cyst of the cystic duct: a case report. Surg Laparosc Endosc 1998;8(05):376-379

8 Baj M, Sengupta S, O'Donnell L. Choledochocele of the cystic duct: a case report. Internet J Gastroenterol 2002;1(02):1-4

9 Weiler H, Grandel A, Frühmorgen P. [Congenital cystic dilatation of the cystic duct associated with an anomalous pancreaticobiliary ductal junction]. Ultraschall Med 2003;24(03):197-201 
10 Manickam S, Ramadan K, Adams BK. A rare choledochal cyst of the cystic duct with an anomalous pancreaticobiliary union in an adult patient. Clin Radiol Extra 2004;59(08):68-71

11 Yoon JH. Magnetic resonance cholangiopancreatography diagnosis of choledochal cyst involving the cystic duct: report of three cases. Br J Radiol 2011;84(997):e18-e22

12 Chan ES, Auyang ED, Hungness ES. Laparoscopic management of a cystic duct cyst. JSLS 2009;13(03):436-440

13 Conway WC, Telian SH, Wasif N, Gagandeep S. Type VI biliary cyst: report of a case. Surg Today 2009;39(01):77-79

14 Ghatak S. Type IV A choledochal cyst with cystic duct cyst. HPB (Oxford) 2010;12(04):285

15 Khanna M, Buddhavarapu SR, Heena H, Amir E. EJR 2010;75: e63-e67

16 De U, Das S, Sarkar S. Type VI choledochal cyst revisited. Singapore Med J 2011;52(05):e91-e93

17 Maheshwari P. Cystic malformation of cystic duct: 10 cases and review of literature. World J Radiol 2012;4(09):413-417

18 Shah OJ, Shera A, Shah P, Robbani I. Cystic dilatation of the cystic duct: a type 6 biliary cyst. Indian J Surg 2013;75 (Suppl 1):500-502

19 Mishra PK, Ramaswamy D, Saluja SS, Patil N, Chandrashekhar S. Unusual variants of choledochal cyst: how to classify. Am Surg 2013;79(04):E162-E164
20 Kesici U, Kesici S, Tüten A. Cystic duct cyst: report of one case. Turk J Gastroenterol 2013;24(02):170-172

21 Sethi S, Upreti L, Verma AK, Puri SK. Choledochal cyst of the cystic duct: Report of imaging findings in three cases and review of literature. Indian J Radiol Imaging 2015;25(03):315-320

22 Çamlıdağ İ, Nural MS, Danacı M, Karabıçak İ, Karabulut K. Chalangiocarcinoma arising from a type VI biliary cyst: a case report and review of the literature. Case Rep Radiol 2015;2015:625715

23 Nambiar L, Alex A, Siskind E, et al. Type VI choledochal cyst-an unusual presentation of jaundice. Int J Angiol 2016;25(04): 263-265

24 Ray S, Bhat BK, Yadav A, Nundy S. Isolated dilatation of the cystic duct-type VI choledochal cyst: a rare case presentation and review of the literature. J Surg Case Rep 2017;2017(04):rjx067

25 Singham J, Yoshida EM, Scudamore $\mathrm{CH}$. Choledochal cysts: part 1 of 3: classification and pathogenesis. Can J Surg 2009;52(05): 434-440

26 Singham J, Yoshida EM, Scudamore $\mathrm{CH}$. Choledochal cysts: part 2 of 3: Diagnosis. Can J Surg 2009;52(06):506-511

27 Bheerappa N, Sastry RA. Pancreatico-biliary ductal union. Trop Gastroenterol 2001;22(04):190-193

28 Upadhyaya VD, Kumar B, Upadhyaya E, Neeyaz Z. Choledochal cyst of cystic duct in children a rare entity. Kathmandu Univ Med J 2018;64(04):354-358 